\title{
The Evolution of the Quality Agenda in Higher Education: The Politics of Legitimation
}

Ourania Filippakou, University of Hull

\begin{abstract}
Taking the evolution of the quality agenda in the UK as its centrepiece, this article analyses the politics of legitimation accompanying the emergence of quality assurance and the contribution of quality enhancement to the power play therein. This article argues that over the last twenty-five years the quality agenda has been used as a proxy - a state steering mechanism - to fulfil political ends and that two trends mark that history: the rise of the regulatory state and the development of quasi-markets. The article also places these issues into the contexts of globalisation and the emergence of regions of quality assurance around the world. However, what shapes the article is not this argument per se, but trying critically to reflect on the quality agenda as a political position, and see the ways in which the epistemology of higher education is embedded in the politics of both national reforms and international political relations.
\end{abstract}

Keywords: quality, ideology, discourse, legitimacy, marketization, regulation.

\section{Introduction}

This conceptual article revisits a topic central to higher education: the theme of 'quality'.

Taking the evolution of the quality agenda in the UK as its centerpiece, this article analyses the politics of legitimation accompanying the emergence of quality assurance, and the contribution of quality enhancement to the accompanying power play. It outlines three ideas. Firstly, it explores the nature of the legitimation problem of the quality agenda and considers the extent to which quality assurance agencies can be regarded as an epistemic community capable of responding to that problem through a regulatory contribution. Secondly, drawing on interviews with key players in the development of the quality agenda, and a range of documentary sources, it examines the policy discourse of quality assurance in terms of the balance of power expressed therein. Thirdly, the article notes that the theme of 'quality' is far broader than just developing a quality assurance process. The analysis deals with the contribution of the international discourse and networks of 'quality' to the evolving policy debate in England of higher education regulation within the context of increasing marketization. 
The empirical focus is the UK quality agenda, and particularly England. England has probably the most mature quality system in Europe and now one of the most heavily marketized systems of undergraduate education in the world. However it is important to recognise that higher education has been part of a more profound force of globalization (King 2009) and, similarly, we can quickly focus the significance of that issue if we see it in a comparative light. Developments in quality arrangements in higher education take place not only within the context of the nation state but also within the context of supranational organizations and new regional actors have developed and lead to new forms of governance. The last part of the paper, therefore, will place the discussion into a wider context, particularly that of the European Union and the Bologna Process.

The purpose of this article is to begin the development of an analytical framework through which the quality agenda and its implications for higher education can be better understood. In order to experience the politics inherent in such an endeavor, and to make the discussion somewhat more concrete, parts of policy texts will be discussed. Other empirical data are drawn from interviews with senior members of the main 'quality bodies' in the UK and Europe, particularly the Council for National Academic Awards (CNAA), the Higher Education Quality Council (HEQC), the Academic Audit Unit (AAU), the Quality Assurance Agency, and the European Association for Quality Assurance in Higher Education (ENQA) as well other key players and analysts in the quality debate. The interviews were conducted between 2004 and 2009, and the interview data are used mainly to illustrate the argument of the article and can be seen as examples of how the quality agenda is being perceived by key policy actors. 
The article argues that the quality agenda has been used as a proxy for the state to fulfil political ends and, through the use of quality as a state steering mechanism, two trends mark that history: the rise of the 'regulatory state' (Neave 2012) and the development of 'quasimarkets' (Williams 2004). The quality agenda underpinned, gave meaning to the structures, processes and practices of higher education systems, to both teaching and learning; and in many ways it is still expected to do so. However, what shapes the article is not this argument per se, but trying critically to reflect on the quality agenda as an epistemic and political position, and see the ways in which the epistemology of higher education is embedded in the politics of both national reforms and international political relations. The conclusion of the article is that we have some unexpected challenges to resolve, including complex questions about policy transfer and power asymmetries.

\section{The current problem}

Following the announcement of the new Teaching Excellence Framework (TEF) for monitoring teaching quality in England, to replace the current quality assurance system of cyclical inspection (Jo Johnson, $1^{\text {st }}$ July 2015) on Friday 6th November 2015, the UK government released a Green Paper on Higher Education for a Teaching Excellence Framework. The political significance of the Framework was summed up by Jo Johnson, the Minister of State for Universities and Science, who commented: 'While there is a lot of excellence, there is also, as the sector acknowledges patchiness and variability in and between institutions. We're helping the sector address that patchiness so we drive up the quality of teaching for everybody... Students should come out of their university years feeling they've got value for money for their time there.' (Guardian, $6^{\text {th }}$ Nov 2015). Although the notion of an explicit dependency between a new endeavour and the legitimacy necessary to maintain public trust in that endeavour is not new, the form of its realization in the case of the 
teaching quality agenda highlights the problem of legitimation faced by the increasing marketization of higher education.

Public trust in the quality agenda which combines institutional information about the quality of teaching and learning practices would not be problematic if the only foreseeable consequence was the opportunity to improve public higher education by understanding the interaction between pedagogical practices and the learning environment without encouraging the marketisation of higher education and offending traditional academic norms. Since this is not the case, and since the regulation of higher education has consistently demonstrated the sensitivity of the social context in the translation from policy to implementation, in which the politics of legitimation form a natural part of policy implementation. 'Legitimations are the claims that dominant groups make about themselves - claims that they would naturally wish everyone else to accept. Legitimacy, on the other hand, refers to the contribution in which such claims have in fact been accepted and endorsed by subordinate groups'. (Weber in Parkin, 2000: 77-78).

Legitimacy can be defined as 'the capacity of the system to engender and maintain the belief that the existing political institutions are the most appropriate ones for the society' (Lipset 1959: 77). Legitimacy gives authority to an institution, and in effect sanctions its power. It makes institutions valid in a society. In his book, Legitimation of Belief, Ernest Gellner (1974: 24) describes legitimacy as the term that conveys the fact that 'such and such a personage, institution or procedure is held to be authoritative, binding or valid in a given society'. If this belief is not present, or if it exists in only tenuous form, a government's ability to formulate and implement policy will be inhibited by its key stakeholders' lack of trust in its institutional processes and outcomes (Dogan 1992). Stakeholders may decide not 
to co-operate, to co-operate partially, or actively to oppose a particular policy initiative. Institutional legitimacy is, therefore, a sine qua non of any new policy development and it is of great importance for initiatives such as the quality agenda which has been dependent on the active co-operation of universities.

The opposition to the creation of the teaching quality agenda and, therefore, legitimation problems, is often expressed in concerns about the allegedly unique nature of higher education and the implications for surveillance, state control, social justice and commercialisation (Collini 2012; Nixon 2001; Scott 2015). The extent to which a governance framework can protect higher education directly impacts on public trust in this regulatory field (King \& Norton 2013). At the same time, one should not forget that whatever form of regulation is adopted has to be seen as legitimate by key stakeholders such as the academic community and the students (Clark 1983; Barnett 1992). Where industry is content with a regulatory framework that facilitates its economic interests, society more broadly may feel that certain public interests have been compromised in the interests of commercialisation (Bok 2003; Dill 2003). Alternatively, societal stakeholders may be content with arrangements that industry may regard as a constraint on its activities (Bok 2003). Thus, and as government has clearly recognized, higher education markets are dependent on the construction of particular forms of regulatory legitimacies (cf. Habermas 1976).

When an issue such as the quality agenda is politicized, a policy community may feel that the construction of different forms of legitimacies is more appropriately achieved through an adaptation of the familiar than through the development of new institutional arrangements (cf. Weber 1970). The conventional approach to regulation has relied on technocratic epistemic communities to provide a 'rational' basis for policy decisions (Haas 1992). 
However, the experience of the quality agenda has demonstrated the limited utility of the technocratic approach as seen by the increasing marketisation of higher education. In such a situation it can be anticipated that the state will turn to a familiar legitimation device - the use of an epistemic community - but also rearrange the order of discourses required (cf. Foucault 1971, 2004).

\section{The nearly contemporary}

In the UK 'quality' emerged as a term with political currency in the early 1990s when the higher education discourse became engaged in the quality agenda, employing a variety of approaches and methodologies (Salter \& Tapper 2000). Since the abolition of the binary line between polytechnics and universities in 1992, several institutional forms of 'quality' have been established with state support: the AAU, the HEQC, the QAA, and the Higher Education Academy (HEA) (Brown 2004). So in the UK, public support for the quality agenda has been assured through governmental regulatory arrangements that have relied heavily for their legitimacy on the authority of 'quasi-state institutions' (Filippakou \& Tapper 2010). Characterized as the 'technocratic approach', these arrangements have usually taken the form of expert advisory groups closely integrated with the bureaucratic apparatus of regulatory policy-making and implementation (Goodwin \& Grix 2011).

However, while the idea of quality has been institutionalised, there is considerable political struggle as the quality movement becomes an indicator of political tension (cf. Brown 2004). Furthermore, as the political pressures for marketization intensify, there is a natural tendency for that agenda to be reformulated in response (Palfreyman \& Tapper 2014). As the Green Paper (BIS 2015) implies, this approach has attempted to deal with the pressures generated by increasing diversity and marketisation. In the case of the Green Paper proposals most 
institutional responses showed themselves to be at least as concerned about its implications for their cultural values as for the linkage between TEF and fees (UUK 2016).

Despite the political struggles, the institutions of quality since 1992 share a common agenda, derived from the principles of increasing state control and more recently the marketisation agenda. These principles can be expressed as a set of methodologies, and in the following sections I offer an overview of the different elements and methodologies adopted by the different institutions of 'quality' in the UK. There are discontinuities but also continuities, which can help to sharpen contemporary questions about 'ways of understanding' the quality agenda as well as the condition of higher education.

\section{External examiners}

The idea of academic standards was always a concern for UK higher education. UK higher education is distinct from other European higher education systems for its tradition of selfregulation, as academics in British universities had invented their own way to maintain academic standards with the system of external examiners. Nowadays the system of external examiners remains one element of quality assurance, whilst in the past it was a system in its own right.

The origins of the external examiner system can be traced back to 1832 when the University of Durham was established (Silver 1996). External examiners reports became one of the key elements in national quality assurance systems. However, in the 1990s doubts started to be raised, that the system of external examiners is a method that cannot assure comparability between programmes at the national level (UK interviewee). Specifically, it was the Dearing Committee that proposed a more 'professional' approach to the work of the external 
examiners. This resulted in Recommendation 25, that its early work should include drawing up a UK-wide pool of academic staff recognized by the QAA from which institutions must select external examiners: 'The remit of the external examiner will need to be consistent across the UK, necessitating thorough familiarization, training and preparation, including a trainee/apprentice model for new external examiners'. The government accepted all the recommendations concerning the quality agenda from the Dearing Report. However, the QAA - in the October 1998 issue of its bulletin, entitled the 'Way Ahead' - announced that '[w]e are not proceeding with that proposal', although the external examiner system is still discussed at policy making level.

\section{The polytechnic sector and the Council for National Academic Awards}

The history of quality in the UK higher education - in its institutional form and at national level - originates mainly from within the non-university sector of higher education. Although there had been prior regulatory bodies, a critical development was the creation of the CNAA. It was a degree awarding body established by Royal Charter in 1964 and disestablished in 1992, when the polytechnics could apply for the university title.

The Council's main power was to award degrees to persons who had pursued 'courses of study at educational and research establishments other than universities, and they were required to be comparable in standards to university awards' (Lewis, 1990: 3). 'To gain approval, the institution had to satisfy the CNAA that it had the necessary overall facilities and quality control systems' (Silver, 1990: 3). There were visits to the institutions, while there was also an interaction between the members of the CNAA and the course team. For some commentators, this interaction was characterized mainly by 'critical dialogue' (Barnett 1988). 
As Brown observes (2004: 36), 'the CNAA was not just a regulatory body... It explored and in effect legitimized a series of developments which together transformed higher education'. The idea of the course team and the course leader has its origins in the polytechnic sector and the CNAA also introduced new subjects like business studies as well as new means of delivering programmes such as part-time degrees and modularization. Other examples were new ways of organizing learning such as independent learning and credit accumulation and transfer (Brown, ibid). Thus, it might be argued that the CNAA constructed new modes of higher education and - after the abolition of the binary line in 1992 - it still had a tacit impact on the UK system, as many traditional universities adopted these new modes of higher education.

\section{The Academic Audit Unit}

The AAU was the first external body for quality assurance in the university sector. It was established by the Committee of Vice Chancellors and Principals (CVCP) in September 1990 and disbanded in July 1992. For one of the interviewees, the AAU was 'essentially defensive... the universities were worried that the Government was going to try and impose an inspectorate on them of one sort of another'. A similar argument has been made also by Yorke (1996: 8): 'it was widely believed at that time that the CVCP's initiative would preempt Government plans for the establishment of an independent external agency to undertake work of this kind'. In other words, the AAU was established by the sector itself in order to avoid state intervention.

The aim of the AAU was to examine the quality assurance systems of universities and report on their effectiveness (Yorke, 1996: 8). There were four main areas that were looked at: (i) programmes; (ii) teaching and learning; (iii) external examiners; and (iv) feedback to the 
course team. As its title indicates, audit was the main element of the AAU. '[T]he technique we adopted was first of all documentation, secondly a visit and then thirdly a draft report which we showed to them and then we put a final report... there was no self evaluation' (AAU interviewee). The reports of the AAU audits were not formally published by CVCP, as they were the property of the relevant institutions, but nearly all those audited have placed their reports in the public domain (Williams, 1994: vii). In the end institutions decided to make them publicly available when one institution's report (at the institutions' instigation) was published in the Times Higher Education Supplement (AAU interviewee).

As an interviewee suggests, the AAU was undermined mainly because the government wanted to shift to inspections (an idea derived from school inspections): 'It was quite clear to us, that, they weren't interested in what we were doing; they had decided that they were going to have an inspection'. Similarly, a former vice-chancellor observes: 'The state was looking for wrong-doing and the thing about this there was a stage when its inspectorate in the secondary schools in the school system, OFSTED, under an ideologue, going round telling the Government that something like 1 in 10 secondary schools was failing'.

The Funding Councils and the Higher Education Quality Council

The Funding Councils until now have an important role to play in the national quality assurance arrangements. Immediately after the passage of the 1992 Further and Higher Education Act, HEFCE became the main body responsible for quality assurance in England, and with the abolition of the binary line between universities and polytechnics we also see the disbanding of the CNAA and the AAU. 
The HEQC took over responsibility for quality assurance, largely using the procedures of the AAU and drawing upon the staff of the CNAA and the Inspectorate, while in 1993 a new methodological element was introduced in the assessment of quality, which was the so-called 'subject review'. The initial post-1992 years saw two main streams of quality assurance: one led by the Quality Assessment Committee (QAC) and the other by the Higher Education Quality Council (HEQC). 'The QAC (as suggested by its very title) had a statutory obligation to assess institutional quality and report back to the Funding Council, whereas the HEQC was responsible to its founding bodies (CVCP, CDP and SCOP) and engaged essentially in institutional audit.' (Tapper, 2007: 180). However, '[t]here was widespread agreement that this was an inefficient and costly regulatory model, and the purpose of quality assurance needed to be redefined and made the responsibility of one body' (Tapper, ibid). In 1997, therefore, the HEQC was abolished and the QAA was established and took over its tasks.

It is also the first time that the term 'quality' appears in the title of an institution in relation to higher education in the UK. The principal element of the methodological profile of the HEQC was institutional audit, while its main aims were accountability and quality enhancement (Williams, 1994: paragraph 2, iv). One of the principal aims of the audit was 'to give institutions an opportunity to render themselves accountable for the quality of their educational provision to all those who have a legitimate interest in what is being offered in higher education' (ibid). There was a three-day visit by three auditors who had to analyze 'extensively' institutional documentation. 'Reports, usually about 10,000-12,000 words long, have both formative and judgmental elements, but do not offer categorical judgments of the 'satisfactory/unsatisfactory' type. They are published by HEQC' (Williams, 1994: vii). 'Audit procedures published reports which in effect give a picture of the strengths and weaknesses of quality assurance at the university or college concerned' (HEQC, 1995: 1). 
The goal for all this was 'quality enhancement and dissemination of good practice' by the Council's Quality Enhancement Group (HEQC interviewee).

\section{The Quality Assurance Agency}

The QAA was established in 1997 'to provide an integrated quality assurance service for UK higher education' (QAA 2008). This integrated quality assurance service was an attempt to combine course and institutional evaluation. It was established by the Joint Planning Group (JPG) in an attempt to create a structure that would amalgamate the two quality assurance models. Tapper (2007), has described this outcome - the establishment of the QAA - as a 'politically constructed' product: the representative higher education bodies would constitute the company (that is the QAA), while its board of directors was to be a mixture of members drawn from those representative bodies and the funding councils but also to incorporate six so-called 'independent' directors who would be 'representative of the wider community with an interest in quality and standards in higher education' (CVCP/HEFCE, September 1996 in Tapper, 2007: 21).

There are, at least, two eras for the QAA - from 1997 to 2001 and from 2001 to the present. The first period ends with the resignation, on $21^{\text {st }}$ August 2001, of John Randall, the Chief Executive of the QAA. There was a transitional period and, then, Peter Williams took over as the new Chief Executive. The main difference between the two eras of the QAA is that in the former era the QAA included a scoring method in its methodology. The subject review was an element that the QAA had inherited from HEFCE/HEQC. However, the subject reviews, and particularly the numerical scoring, were heavily criticized by the academic community leading to a crisis in the QAA's methodology. 
The growing hostility was most vividly illustrated by the response of Warwick University's Economics Department to its QAA inspection, which resulted in the award of the maximum score of $24-$ 'We have to stop the QAA monster or it will eat us alive'! (Macleod, 30 ${ }^{\text {th }}$ January 2001). The subject review element was characterized as 'the most damaging and destructive system of regulation that could possibly has ever been devised' (ibid). What the six Professors at Warwick were arguing was that the QAA methodology was not scientific and objective as the QAA presented it: as the scores were based in part on how institutions presented themselves, and that the QAA changed its methodology over time making comparability impossible.

The second era of the QAA (2001- to the present) is characterized by a 'lighter touch' methodology. There are two reasons for this claim. First, the QAA abandoned, except in exceptional cases, subject reviews along with the numerical scores that accompanied those reviews. Second, it switched its attention from courses to institutions (i.e. institutional review/audit). Moreover, these developments have been reinforced by the arrival of the National Student Survey (NSS). The latter was an initiative of HEFCE, which exercises its overall statutory authority for quality through its Quality Assessment Committee (QAC).

In its Strategic Plan 2006-11, the QAA announced a new way forward: 'maximizing the benefits of our work by devoting more resources to development and enhancement across the UK' (QAA 2008). Was this an indicator of the limitations of quality assurance? One of the main challenges for the QAA had been the idea of 'quality assurance' itself. Although they bear the title 'quality assurance agency', as an interviewee from the QAA directorate suggested, 'quality assurance agencies can't assure quality. They can observe, comment, report or make recommendations. Only the people providing the programmes can actually 
assure quality'. Similarly, a senior member of the HEQC observes: 'you cannot create quality from the outside'. After almost twenty years of quality assurance procedures in the UK, it can be argued that 'quality assurance' in itself is limited.

\section{A schematic summary}

It is possible now, therefore, to set out in schematic form the major constituents of quality assurance methodologies (see table 1). They can be listed as follows:

- Visits

- Subject/course focus

- Institutional focus

- Interaction with course team

- External examiners and their reports

- Scoring methods/numerical approach

- Audit

- Public reports

Methodologies are derived from the quality assessment institutions, which have their preferred models with prohibitions on alternative approaches. Several elements will comprise a quality profile, but each such element has to be understood with the other elements. For example, the subject review had a different meaning dependent upon the scoring method; or the 'new' QAA approach contributed to the rise of a managerial discourse, as after the establishment of the QAA, universities had to appoint quality managers in order to respond to a more complex QAA methodology (see table 1). There may be structures that offer no space for interaction between quality assurance institutions and universities, no space for dialogue (for example the numerical approach), especially where the power difference is notable. A large differential in power can be used by a quality agency to control and structure the interaction. Legitimacy, therefore, in a quality system may be defined by the particular 
distribution of power, and the sections above have presented a broad overview of the evolution of the structures and process of quality assurance in the UK to illustrate that point.

Table 1: Quality elements of different quality bodies in England (including the CNAA)

[Insert Table 1 here - please see page 30]

\section{$\underline{\text { Key }}$ Explanation}

$(\vee \quad$ not compulsory methodological element but occasionally present

$\checkmark \quad$ compulsory methodological element

$\checkmark \vee \quad$ compulsory and important methodological element

$\checkmark \vee V$ compulsory and dominant methodological element

$\times \quad$ absence of the particular methodological element

\section{The contemporary}

Quality mechanisms such as the QAA in the UK are designed to collect information, link with institutional and other data, and evaluate the teaching and learning infrastructure of higher education providers with a particular focus on academic standards. Of themselves some of these processes are not new. What is new and politically sensitive as seen in the new Green Paper (2015) and the proposed TEF is the combining of the teaching quality and fees. The ready justification for this endeavour is that:

'The TEF will increase students' understanding of what they are getting for their money and improve the value they derive from their investment, protecting the interest of the taxpayer who supports the system through provision of student loans. It should also provide better signalling for employers as to which providers they can trust to produce highly skilled graduates' (BIS, 2015: 12-13).

However, for universities the attractions of the TEF are less obvious. The TEF constitutes a form of information, which in turn poses concerns about the issue of academic standards and 
its handling compared to previous quality reviews. Although current quality reviews may contain similar information about an institution, and both are publicly available, the new proposals links fee caps to multiple levels of TEF. A key question now arises: under market conditions, where higher education is itself being marketized, is a quality assurance system needed? And, if so, what is its role to be?

As the UK government recognised, the higher education market is now seen to require a 'robust framework' if they are to carry out their work with the active support of its key stakeholders such as students and universities. Thus the quality discourse is elevated to the status of a sine qua non of the marketisation project. For students this can be construed as a discourse regarding the use of the teaching quality information where the key question is the relationship between, on the one hand, their interests as consumers over that information (BIS, 2015: 59) and, on the other, the interests of the universities, employers and the state. Effectively, then, what we are looking at is an interests-based discourse of power over the control of higher education which, depending on the juxtapositioning of the values within that discourse, will establish and legitimate a particular balance of power between the participants. To the extent that students' interests over the teaching quality information are expanded or contracted, so also is the nature of higher education.

Certainly, the UK government is aware that the political sensitivity of the increasing marketisation of higher education requires changes in the form of its regulation (King \& Norton 2013). Its 2010 review of the Browne advisory review for the future of higher education funding in England concluded with a commitment to 'choice' in terms of enhanced 'quality', 'public interest' and broadened definitions of 'higher education' (Browne 2010). The political ambition of these recommendations was to use the principle of 'choice' as a 
source of free market economy to shore up the legitimacy of the advice and decisions of the regulatory committees.

However, choice is, at best, a vague and ill-defined response to the political problem of regulatory legitimacy (cf. Apple 2005; Olssen \& Peters 2005), often regarded with suspicion and hostility by the established culture of the UK's academic and student body (Reay et al 2001). Questions such as what choice means in practice and how the criteria for new higher education providers should be determined, or whether relying on the prospect of relevant information being put into the public domain so that students can make well-informed, or even 'rational' choices, is a feasible agenda, and have become the object of political wrangling (cf. Giroux 2015). Thus, the 'public realm', as described by Foucault (1990), is gradually being restricted by the infusion of private financial arrangements into public institutions (cf. McGettigan 2013), and the concept of 'governmentality' further adds to this an analysis of the individualization of subjectivity, as the public identity of 'citizen' is replaced by discourses of 'consumer choice' and 'personal responsibility' (Foucault 1991, Rose 1999).

From this perspective it is not surprising that one of the most notable political consequences of the uncertainties surrounding the new quality agenda has been the adaptation of regulatory forms to include expert committees dealing with, and pronouncing on, the economic implications of higher education. Their purpose is to routinize the discussion of the economic rationality of higher education and provide an authoritative means for resolving political struggles. Accompanying this new legitimating function has been a new discourse as a descriptor for the committees, that of 'social mobility' and 'widening participation' (cf. BIS, 2015: 36). However, system stratification tends to reinforce social stratification (Marginson 
2016), and the intended differential levels of institutional income, deriving from different TEF evaluations, and the greater institutional hierarchies that this is likely to bring should lead to a rise in social inequality.

Currently interpretations of the development of the new field of quality differ markedly in terms of such basic questions as 'what it is' and 'where it is going'. As discussed previously, there is an evolutionary process through three phases of 'quality assurance', 'light touch' quality assurance and, finally, 'quality enhancement'. Thus there has been energetic debate over the need for quality assurance, on the one hand, to adopt coherent principles and rules and, on the other, to incorporate an appropriate recognition of institutional diversity and, therefore, focus on quality enhancement. Meanwhile, some external critiques have viewed its origins as more political than ethical, driven by the utilitarian service of interests rather than the focus on 'enhancement' as such. To that extent the quality agenda may be portrayed as performing the classic function of an ideology as much as that of socio-political activity. However the term 'quality enhancement' hardly appears in the new Green Paper. The Green Paper primarily focuses on 'teaching excellence' and 'regulation', while 'quality enhancement' within the context of 'teaching excellence' seems to be the role of the Higher Education Academy (HEA 2016). But 'excellence' is, at least, an 'empty concept' (cf. Readings 1996), if not as ‘ideologically heavy’ as quality assurance (Filippakou 2011).

One of the conclusions of the English experience so far is that the rise of the quality assurance discourse changed the power relations of governance, with the state having more power, and the quality agenda becomes a vehicle for advancing a further ideological project, that of the market. Specifically: 
(i) higher education appears not only as a product itself but also is developing its own market;

(ii) higher education is expected to focus on 'employers' interests and employability;

(iii) 'training' and the 'skills agenda' are being promoted;

(iv) the student is a 'customer' and universities become 'providers';

(v) learning is translated into applied economic value;

(vi)often research attracts its own quality assurance systems and the presence of parallel quality systems (for teaching and for research) has been a contributory factor in driving a wedge between research and teaching. It has also undermined the importance of the presence of both for the existence of a university, while the new TEF should enable teaching focused private providers to compete on a 'level playing field' (BIS 2015).

With the emergence of the European Higher Education Area it looked like that the European higher education systems were moving towards a centralised model of control but now with the emergence of TEF (and increasing market forces) in the UK and the Brexit vote, England may move in a different direction. Under conditions of marketization, quality assurance becomes a market-oriented steering mechanism, intended to increase the power of studentsas-customers (as the earlier efforts to create a market and differences in fee levels have largely failed). Are there strong enough historical and cultural links to bind the different national systems together to sustain a common framework of quality control? Or will different national political pressures push them in varying directions with England moving towards the US model (cf. Palfreyman \& Tapper 2014)? What is the possibility of crossadoption, or a pan-European quality assurance system, in the light of these developments? Or will the widely shared power of the market be the unifying driving force? 


\section{A note on the discourse of quality and the 'European' quality agenda}

Quality assurance agencies may not be a united epistemic community but it is an influential transnational policy network capable of working across the political spaces of multi-level governance to help shape the national politics of the legitimation of the quality agenda. At the European Union (EU) level, '(f)ollowing the Recommendation of the Council (98/561/EC of 24 September 1998) on European co-operation in quality assurance in higher education and the Bologna Declaration of 1999', the European Network for Quality Assurance Agencies (ENQA), and the European Quality Assurance Register (EQAR) have played an important role in the development of new regulatory mechanisms, particularly in relation to quality assurance and accreditation.

Propelled by the continuing activities and reports of the Bologna Process, the Declaration has acted as the template and rationale for a series of quality initiatives by different national states. The Bologna Process is a reform based on the Lisbon Strategy (March 2000) (European Commission 2016) whose aim is the economic development of Europe and universities are seen as part of this economic growth. To reach that goal, quality mechanisms have been very important:

'The key players are the Ministers, the Commission; and the Commission has its own agenda here. The Commission wants a very, very instrumental higher education system across Europe, the more centralized, homogenized it is, the better from their point of view. So they don't like all these national systems because it, they think that, with some justification weaker countries will have no incentive actually to modernize and improve and reform...' (ENQA interviewee). 
Despite the national differences, the European Commission has succeeded in pushing the quality agenda and we see quality as an 'evolutionary' process: 'What the universities are going to do when they see these, well, what, they just won't understand and when we wrote the standards and guidelines we make it very clear that this is a process, this is a evolutionary process...' (ENQA board member). To illustrate the picture schematically, quality systems can be located somewhere within the following quadrants (diagram 1).

Diagram 1: A diagrammatic representation of national quality systems

[Please insert diagram 1: page 31]

This diagram prompts the following considerations:

a) Empirically, most national systems are above the horizontal line, that is, they have been dominated by quality assurance.

b) The space below the horizontal line (i.e. national quality systems driven by quality enhancement) is a theoretical space which is very thinly populated at the moment.

c) The space below the horizontal line is an opportunistic space in the sense that it offers opportunities for the development of national quality systems. In the UK, particularly in England and Wales, we saw a migration - the system was moving from above to below the horizontal line, from quality assurance to enhancement but 'excellence' can be seen as a strongly codified quality assurance space.

d) We can say that Scotland is probably already below the horizontal line, because it has an enhancement led quality system which, at the same time, is strongly codified (i.e. quadrant 3). 
e) It is probable that quadrant 4 (enhancement led systems which are fluid and less controlled) is currently empty, as there is no empirical evidence to suggest any system inhabits this space.

For many European countries, the 'European dimension' seems to be an important parameter in the formation of the new national quality system. The question is: can this framework represent the voices of all European higher education systems? As another ENQA board member suggests, this is practically impossible: 'Well ENQA, at least in theory, represents the collective voice of quality assurance agencies in Europe. But there is no collective voice because there are 45 different signatories into Bologna, only, not all of them have agencies and all the agencies do different things in different ways'.

It seems, therefore, that a major challenge for any EU policy is cross-adoption. As an interviewee suggested, 'there are dangers if member states do not take into account their contextual differences'; 'quality' is part of the Western European tradition, particularly the Anglo-Saxon countries, and the European guidelines for quality are 'alien' to other European countries: 'But I think we now have the European standards and guidelines which the further east you go across Europe the more alien they are to the traditions... but when you get to some of the more remote European countries and the very, very far east, you will start finding countries saying we do not understand and therefore, or worse than that they'll say yes we understand and think they understand, and pretend they understand but will just carry on doing what they're doing' (ENQA interviewee).

The evidence suggests, therefore, that as an epistemic community the discourse of quality is certainly not yet fully formed. Rather, what we have is a hybrid group of interests drawn from a variety of discourses with a common interest in the definition, organization and application of arguments regarding the future of the quality agenda. Yet despite the self-evident 
inconsistencies and confusions surrounding its identity, the social and political value of the quality label continues to increase when measured in terms of such crude quantitative indices as numbers of courses, conferences, websites and committees. As an epistemic community it may be divided and conflictual but this has in no way inhibited its expansion as a sociopolitical activity and, as the growth of institutions and their role demonstrate, it has political utility. Their influential presence in the higher education discourse can be viewed as a shift from legitimation within states to a regional legitimation and as constituting a natural extension of their political interest in ensuring that the quality agenda continues to achieve its legitimating goals.

There are, however, important implications: there are power asymmetries both among and between states and market interests. It is not just that the procedures may differ but also that the process may serve contrasting policy goals. Any transfer of policy could suggest that a distinctive and deeply-rooted tradition of higher education is under attack, in this case that something more than the instigation of accountability mechanisms and the desire to monitor institutional performance is at stake. The issue, therefore, is whether a policy idea can be transferred across national boundaries in a manner than harmonizes with the established traditions and yet still retains its original purpose. As differences find expression - as in the UK case - the political test of an epistemic community's legitimating strength will be its ability to routinize the discussion of differences and so reconcile national interests with the interests of the supranational state and market.

\section{Conclusion}

In the last three decades the idea of quality in higher education has been re-positioned discursively (in many societies): there are statements which suggest that now many more 
systems than before can and should be doing it; that it is very useful and relevant as a guide to academic standards; and that it has a strong and obvious immediacy in terms of its ability to come to grips the 'Bologna Process'. The ideology of markets and state control in the history of the quality agenda has helped to permit a whole range of institutionalised activities to be gathered together under the concept of 'quality' to the point where serious epistemological, ethical and political confusions are occurring.

The vocabularies of the politics of the quality agenda and higher education rapidly overlap: Europeanisation, harmonisation, modernisation, social capital, lifelong learning, economic competitiveness. Politically, these are already salient policy topics in the European higher education agenda, while discursively (in the higher education journals, in higher education books and conferences) such themes often dominate our paradigmatic intellectual agenda. How did things change so quickly? The answer is that, on the contrary, they changed steadily and slowly.

\section{References}

Apple, M.W. (2005). 'Are markets in education democratic? Neoliberal globalism, vouchers, and the politics of choice', in Apple, M. W., Kenway, J. and M. Singh (eds), Globalizing education. New York; Oxford: Peter Lang.

Barnett, R. (1988). 'Does higher education have aims?', Journal of Philosophy of Education. 22(2): 239-250.

Barnett, R. (1992). Improving higher education. Buckingham: SRHE/ Open University Press. BIS (2010). Securing a sustainable future for higher education (Browne Report). BIS:

London.

BIS (2015). Fulfilling our potential (The Green Paper). London: BIS. 
Bok, D. (2003). Universities in the marketplace. Princeton, N.J., Princeton University Press.

Brown, R. (2004). Quality assurance in higher Education. London: Routledge Falmer.

CHES (1994). Assessment of the quality of higher education. London: Institute of Education.

Clark, B. (1983). The higher education system. Berkeley, Calif.: University of California Press.

Collini, S. (2012). What are universities for? London: Penguin.

Dill, D. D. (2003). 'Allowing the market to rule: the case of the United States', Higher Education Quarterly, 57(2): 136-157.

Dogan, M. (1992). 'Conceptions of legitimacy', in M. Hawkesworth and M. Kogan (eds). Encyclopedia of Government and Politics Vol. 1. London; New York: Routledge.

Filippakou, O. (2011). 'Quality as ideology in higher education: a conceptual approach', in Discourse: Studies in the Cultural Politics of Education. 32(1): 15-28.

Filippakou, O. \& Tapper, T. (2010). 'The state and the quality agenda', Higher Education Policy. 23(4): 475-491.

Foucault, M. (1970). The order of things. Routledge. London.

Foucault, M. (1977). Discipline and punish. Harmondsworth: Penguin.

Foucault, M. (1990). The history of sexuality / Vol.1, The care of the self. London: Penguin.

Foucault, M. (1991). 'Governmentality', in G. Burchell et al (eds.) The Foucault Effect. London: Harvester Wheatsheaf.

Gellner, E. (1970). 'Concepts and society', in B.R. Wilson (ed), Rationality. Oxford: Blackwell.

Giroux, H. (2014). Neoliberalism's war on higher education. Chicago: Haymarket.

Grix, J. \& Goodwin, M. (2011). 'Bringing structures back in: The "governance narrative", the "decentred approach" and "asymmetrical network governance" in the education and sport policy communities', Public Administration. 89(2): 537-556. 
Haas, P. M. (1992). 'Introduction: Epistemic communities and international policy coordination', International Organisation. 46(1): 1-35.

Habermas, J. (1976). Legitimation crisis. Cambridge: Polity Press.

Hammersley-Fletcher, L. \& Qualter, A. (2009). 'From schools to higher education-Neoliberal agendas and implications for autonomy', Journal of Educational Administration and History. 41(4): 363-375.

King, R. (2009). Governing universities globally. Cheltenham: Edward Elgar.

King, R. \& Norton, P. (2013). Regulating higher education. London: Higher Education Commission.

Lewis, R. (1990). 'The current role of the CNAA', in C. Loder (ed), Quality assurance and accountability in higher education. London: Kogan Page, in association with the Institute of Education.

Lipset, S.M. (1959). Political man, the social basis of politics. New York: Doubleday.

Macleod, D. (2001) 'Trial by ordeal'. The Guardian, January 30.

Marginson, S. (2016). 'The worldwide trend to high participation higher education: dynamics of social stratification in inclusive systems', Higher Education. Available at: $\underline{\text { http://link.springer.com/article/10.1007/s10734-016-0016-X }}$

McGettigan, A. (2013). The great university gamble. London: Pluto Press.

NCIHE (1997). Higher education in the learning society (The Dearing Report). London: Stationery Office.

Neave, G. (2012). The evaluative state, institutional autonomy and re-engineering higher education in Western Europe. Basingstoke; New York, N.Y.: Palgrave Macmillan.

Nixon, J. (2011). Higher education and the public good. London; New York: Bloomsbury.

Olssen, M. \& Peters, M. (2005). 'Neoliberalism, higher education and the knowledge economy', Journal of Education Policy. 20(3): 313-345. 
Palfreyman, D. \& Tapper, T. (2014) Reshaping the university. Oxford: Oxford University Press.

Parkin, F. (2000). Max Weber. London: Routledge.

QAA (2006). Strategic Plan 2006-2011. Gloucester: QAA.

QAA (1998). 'The way ahead', Higher Quality. 1(4). Gloucester: QAA.

Reay, D. Davies, J., David, M. and Ball, S. J. (2001). 'Choices of degree or degrees of choice? Class, 'race' and the higher education choice process', Sociology. 35(4): 855874.

Readings, B. (1996). The university in ruins. Cambridge, Mass: Harvard UP.

Rose, N. (1999). Powers of freedom. Cambridge: Cambridge University Press.

Salter B. and Tapper. T. (2000). 'The politics of governance in higher education: the case of quality assurance', Political Studies. 48: 66-87.

Scott, G. P. (2014). 'Higher education, the public good and the public interest', in O. Filippakou \& G. Williams (eds.). Higher education as a public good. New York: Peter Lang.

Silver, S. (1990). A higher education: the CNAA and British higher education 1964-89. London: Falmer.

Tapper, T. (2007). The governance of British higher education. Dordrecht: Springer.

Weber, M. (1970). From Max Weber essays in sociology. London: Routledge.

Williams, G. (2004). 'The higher education market in the United Kingdom', in P. Teixeira, B. Jongbloed, D.D Dill and A. Amaral (eds), in Markets in higher education: Rhetoric or reality?. London: Kluwer Academic Publishers.

Williams, P. (1992). 'The UK Academic Audit', in A. Craft, Quality assurance in higher education. London: Falmer. 
Yorke, M. (1996). Indicators of programme quality. London: Higher Education Quality Council.

\section{Websites and electronic sources}

Adams, R. (2015). 'Government plan to allow 'better' universities to raise fees', The Guardian. $6^{\text {th }}$ November. Available at:

http://www.theguardian.com/education/2015/nov/06/government-plan-to-allow-betteruniversities-to-raise-fees. Accessed 10 February 2016.

EC (2016). The Bologna Process and the European Higher Education Area. Available at: http://ec.europa.eu/education/policies/educ/bologna/bologna_en.html. Accessed 20 January 2016.

ENQA (2016). ENQA: History. Available at: http://www.enqa.eu/index.php/aboutenqa/enqa-history/. Accessed 16 January 2016.

HEA (2016). HEA: Quality Enhancement. Available at: https://www.heacademy.ac.uk/heav/quality-enhancement Accessed 20 June 2016.

Johnson, J. ( $1^{\text {st }}$ July 2015). Teaching at the Heart of the System. Available at:

https://www.gov.uk/government/speeches/teaching-at-the-heart-of-the-system. Accessed 10 February 2016.

QAA (2008). QAA: About us. Available at: http://www.qaa.ac.uk/aboutus/qaaIntro/intro.asp. Accessed 10 August 2008.

QAA (2001). QAA: Press releases. Available at: http://www.qaa.ac.uk/news/media/pressreleases/21_aug_2001.asp. Accessed 15 July 2008.

UUK (2016). Fulfilling our potential: teaching excellence, social mobility and student choice - Universities UK response. Available at: 
http://www.universitiesuk.ac.uk/highereducation/Documents/2016/UUKgreenPaperR esponseFINAL.pdf. Accessed 10 February 2016.

Table 1: Quality elements of different quality bodies in England (including the CNAA) 


\begin{tabular}{|c|c|c|c|c|c|c|}
\hline & $\begin{array}{l}\text { CNAA } \\
\\
\\
\\
\\
\\
(1964- \\
1992)\end{array}$ & $\begin{array}{l}\text { AAU } \\
\\
\\
\text { (1990- } \\
1992)\end{array}$ & $\begin{array}{c}\text { FC } \\
\\
\\
\\
(1992- \\
1993) \\
\\
(1993- \\
1997)\end{array}$ & HEQC & $\begin{array}{l}\text { Old style } \\
\text { QAA } \\
\\
(1997- \\
\text { 2001) }\end{array}$ & $\begin{array}{c}\text { New style } \\
\text { QAA }\end{array}$ \\
\hline Visit & $\checkmark$ & 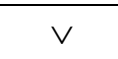 & $x$ & 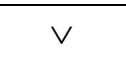 & $\checkmark$ & $\checkmark$ \\
\hline $\begin{array}{l}\text { Subject/course } \\
\text { review }\end{array}$ & 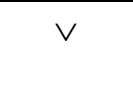 & & 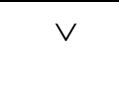 & & $\checkmark V$ & $(\vee)$ \\
\hline Institutional focus & $\checkmark$ & & $x$ & & $\checkmark$ & $\checkmark V$ \\
\hline Public reports & $(v)$ & $(\vee)$ & & $\mathrm{v}$ & $\checkmark$ & $\checkmark$ \\
\hline $\begin{array}{l}\text { Interaction with } \\
\text { course team }\end{array}$ & $\checkmark \vee V$ & & & $(\vee)$ & $(\vee)$ & $\begin{array}{c}(\mathrm{V}) \\
\text { (managers) }\end{array}$ \\
\hline $\begin{array}{l}\text { External examiners } \\
\text { and their reports }\end{array}$ & $\checkmark \vee \vee$ & & & & $\checkmark$ & $\checkmark V$ \\
\hline $\begin{array}{l}\text { Scoring } \\
\text { methods/numerical } \\
\text { approach }\end{array}$ & $x \times x$ & & & $x$ & $\vee \vee \vee$ & $x$ \\
\hline Audit & & $\checkmark \vee V$ & & $\mathrm{v}$ & $\mathrm{v}$ & $\mathrm{v}$ \\
\hline
\end{tabular}


Diagram 1: A diagrammatic representation of national quality systems

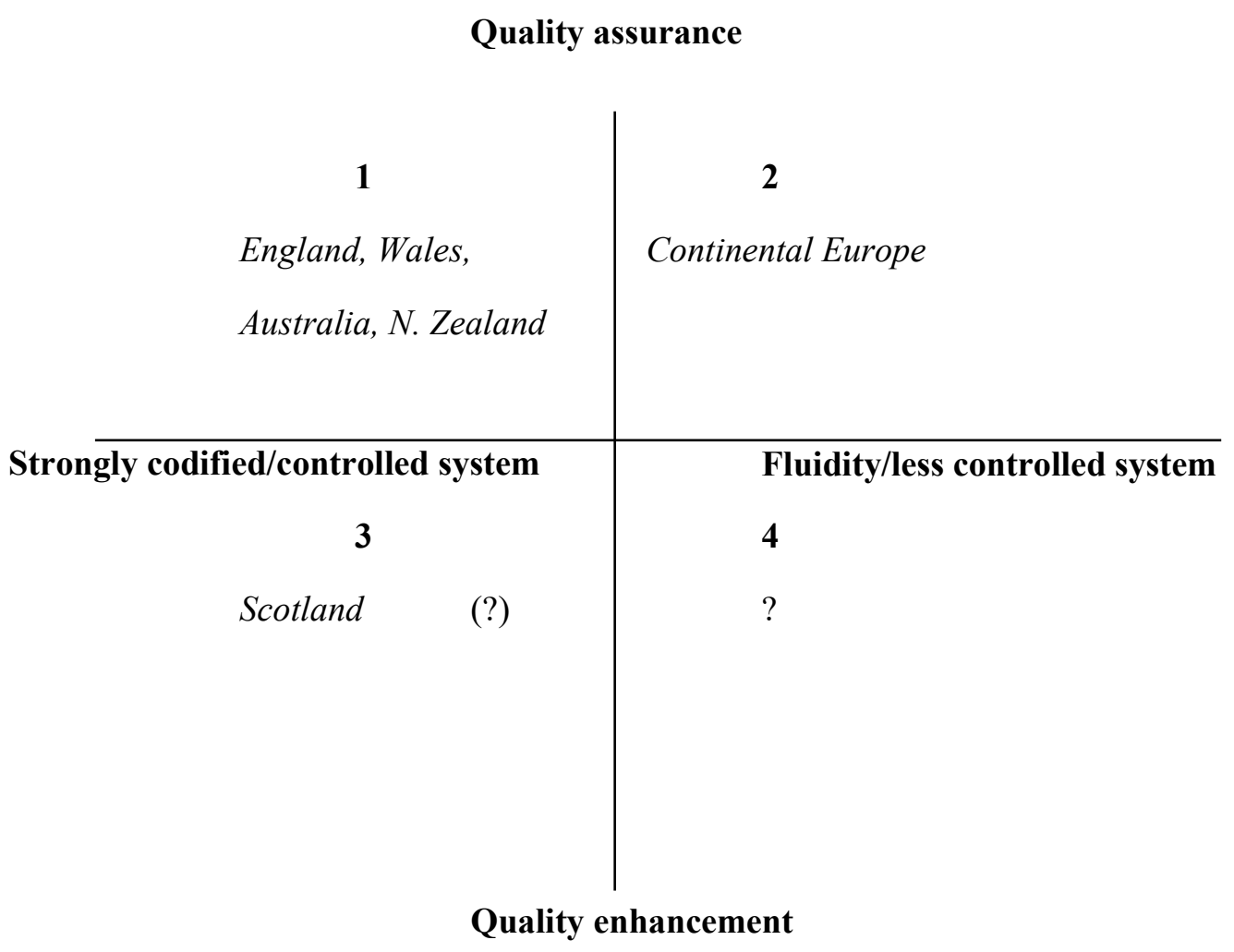

